\title{
Communication and Data Processing in Local Public Group: Transparency and Accountability
}

\author{
Paolo Pietro Biancone ${ }^{1}$, Silvana Secinaro ${ }^{2}$, Valerio Brescia $^{3} \&$ Daniel Iannaci ${ }^{3}$ \\ ${ }^{1}$ Full Professor at the Department of Management, University of Turin, Italy \\ ${ }^{2}$ University Researcher at the Department of Management, University of Turin, Italy \\ ${ }^{3} \mathrm{PhD}$ candidate at the Department of Management, University of Turin, Italy \\ Correspondence: Valerio Brescia, Department of Management, University of Turin, Italy Corso Unione Sovietica \\ 218 Bis, I - 10134 Turin To, Italy. E-mail: valerio.brescia@unito.it
}

Received: June 15, 2018

Accepted: August 10, 2018

Online Published: September 6, 2018

doi:10.5539/ijbm.v13n10p20

URL: https://doi.org/10.5539/ijbm.v13n10p20

\begin{abstract}
The purpose of this story is to identify the role of information in the municipal public group with a view to New Public Governance and the need for mutual exchange between citizens and public bodies. The conducted analysis is quantitative subjective; the theory is demonstrated through the focus of a real case to increase the understanding of theoretical assumptions. The carried-out elaboration, after having identified the variables considered and the possible mathematical relationship between variables. The New Public Governance (NPG) sees public affection closely related to the need for information, this leads to study the real effects towards a new theory of citizen choice. The study shows that the use and dissemination of communication and processing tools in local authorities can have a positive impact on responsibility and transparency, improving trust in local governments and citizen participation in civic or political life. The information provided through open organic data on all sectors ensures greater trust in local public bodies and civic participation. The use of social indicators is a useful tool for assessing population satisfaction and understanding of the information provided to better plan and plan public services and municipal group interventions. The identified tools can be used to analyse the relapse and the involvement of both information and processing tools in the process of communicating the outputs to the stakeholders. All municipal groups have new tools for assessing planning and control. New analysis of the role of information in NPG.
\end{abstract}

Keywords: information, new public governance, processing technologies, communication, public accounting, citizens, stakeholders, public municipal group

\section{Introduction}

The literature identifies a close relationship between the choice and the number of information provided in private companies, always taking into consideration the identifying brand (Jacoby \& Berning 1974; Hu et al., 2009). Information becomes an important factor of choice (Hausman \& Siekpe, 2009). The uncertainty about the choice pushes the consumer to look for information even if their effect does not always have a positive effect on the final alternative, and often the consumer is more confused how much more information he gets (Goodrich, 1978; Jacoby, et al., 1974). The credibility of a brand also has impact on the options considering the cost and the risk to the consumer, moreover the reliability of a service influences them more than the information provided (Erdem \& Swait, 2004). The results indicate that the quality of service persuade the relative attitude and satisfaction in large distributions. The perception of the brand and the information also provided online in private companies have an obvious influence on the choice and consumption, often positive other times for negative data. In private service companies, information processing and communication tools are important. The tools aimed at orienting choices become essential when it comes to the tourism sector (Buhalis, 1998, Melone 1990). More than 180 studies try to afford the topic of public sector knowledge management, but there is no single approach and the issue of the relationship between information, processing tools, accountability and transparency between public and citizen is often relegated to hypothesis (Massaro et al., 2015). Private literature is rich in indications and representations related to the relationship between information, reliability of the brand and of society, propensity to spend based on satisfaction and affection. There is a first analysis of the ratio of consumption choice in public services but only in the health sector based on the satisfaction of previous users (Siliquini et al, 
2011; Lovato, 2011). Other empirical structures have instead shown how the use of telemedicine is linked to the enhancement of patient electronic knowledge (Cegarra-Navarro et al., 2012). There is no relevant theoretical evidence regarding perception of services of the local public group, information to the citizen and processing tools. The Italian state as well as other countries has been engaged for a long time in the definition of a series of social indicators aimed at measuring the perception and satisfaction of the needs of citizens. The post-industrial 21 st-century perspective focuses on the assessment of well-being aimed at answering to needs, rather than focusing on level and production growth. From 1960 to today several studies have been done on the subject. We start from the analysis of Land (2012), Glatzer et al. (2015) by Hagerty and Land (2001), Volger (1999) and Cramm et al. (2012) and finally by Andrews et al. (2015). In Italy the introduction of BES project: the fair and sustainable well-being that has taken place since 2014 by ISTAT CNEL and ISTAT guarantees some reference indicators at national level. The indicators provided in Bes report aim to make the country more aware of its strengths and difficulties to overcome to improve the quality of life of its citizens, placing this concept at the base of public policies and individual choices (Biancone et al., 2017). Citizen participation in public life is a representation of trust in institutions and services satisfaction of production and consumption needs (Kim \& Lee, 2012; Christensen \& Lægreid, 2005; Wang \& War; 2007). The research investigates the effect on responsibility and transparency of the use of communication and processing tools in the local group of municipalities through processing technologies, information for the service provided and accessibility. These evidences are important for governing local public groups and for ensuring choices for citizens by guiding corporate governance in a period of austerity and reduction of available resources.

\section{Literature review}

\subsection{Governance and the Change of Local Public Group}

Reforms related to public bodies' companies (Farnham et al., 2016) suggest that improving governance and accountability mechanisms enhance performances of public sector services, too (Pollitt \& Bouckaert, 2004, 2011). In literature analysis, public sector governance concerns accountability duties in relation to the specific objectives of this area, which are not limited to the provision of services (e.g. cost and quality of services) but include the impact of politics on the community or on society in general (e.g. political outcomes or of taxation-related result) (Jacobs \& Goddard, 2007). Governance includes, in particular, different types of mechanisms and structures that clarify the responsibilities of the various stakeholders about the organization, the implemented approaches, and the ability to meet the demand for responsibility-based transparency through tools such as internal control systems and external responsibility (Goddard, 2005). At present the public company extended to public service companies involved in it, is being considered (Biancone et al., 2016). There has been a gradual shift from New Public Management (Hood, 1991), adopting managerial and business logics to improve its efficiency and inexpensiveness (Boston et al. 1996) to New Public Governance (Osborne, 1992). NPG is the collection of management and leadership practices gradually introduced in the public sector since 1980s. New Public Management is a broad term for a variety of management ideas, often borrowed from the private sector, introducing ideas and tools such as competition, privatization, management by objectives, decentralizations etc. in the public sector (Hood, 1991, 1995). The NPG movement has its origins in a critique of the traditional way of exerting control and management of public organizations and as requirement for increased efficiency in the public sector. This goal is possible through the implementation of a communication path addressed to all stakeholders and to citizenship. Looking at a perspective compared to the various reform experiences, it can be observed that the modernization action was based on the activation of a series of action "levers". In particular, "old" levers and "new" levers can be distinguished, depending on the first embryonic nucleus of NPM or on a more mature phase in which, next to the first critical points, the approach of the Public Governance was progressively emerging (Klijn, 2008). There is a clear change in the approaches that public companies adopt with stakeholders. The "old" levers are based on: decentralization, reshaping, unification, reorganization of public apparatuses, new organizational models and management formulas; competition in the public sector and guided competition between public organizations; "market-like mechanisms", internal markets, sharing, contracting out/in, vouchers, property rights; privatization of public enterprises; evaluation of results and performance, accountability and evaluation of programmed; cash limits, cost-benefit analysis, budget planning, multiannual financial statements, zero-based budget, etc.; management of human resources with devolution of responsibility and flexibility. The "new" levers focus on: greater attention to ethics where an intrinsic ethic of efficiency is discovered; performance and performance contracts and performance-based agreements, territorial pacts, plan contracts; improvement of regulation (Van Dooren et al., 2015). At this stage, the role of public municipalities is based on change management aimed at implementing reform, new information technologies and from efficiency to effectiveness and transition from "information" technologies to "information and communication" 
technologies with an always bigger relationship between public administrations and citizens where improving access and participation, defining quality standards and avoiding patronage becomes a cornerstone of the new trend. Accountability role emerges as a governance tool. One of the tools of New Public Management is the public company's accountability, which is outlined in five principles: responsibility is public and not just internal; it implies explanation and justification not propaganda; it is specifically addressed to a target audience, it is not a casual explanation; it involves an obligation for the actors to come to be accountable; with consequent discussion and evaluation that does not lead to a monologue without commitment of the political actors (Ferlie et al., 2005). The focus of governance has thus shifted to performance evaluation with a system of internal indicators for the same group (Bovens, 2007). Public sector accountability must consider three aspects: compliance, transparency and accountability (Mulgan, 2002). Compliance with New Public Management is defined as the orientation of public companies to bureaucratize company systems (Pollit et al., 1999), although bureaucracy does not necessarily lead to evaluations of results (Hood \& Peters, 2004). Transparency is about sharing information on government decisions and activities, good document management and the access to information is of interest to all segments of the company: investors, the research and development community, the media and citizens municipalities (Relly \& Sabharwal, 2009). Responsibility is a cornerstone of public administration and management because it is the principle that informs the processes that consider people who hold and exercise public authority. Although responsibility regimes vary for important aspects among the political systems, taken collectively, include processes in which citizens hold their own governors to account for their behaviour and performance directly through elections; the spokespeople of the citizens in legislative assemblies hold the political leaders and public officials responsible through public control and control mechanisms; political leaders hold their dependable subordinate officials through hierarchical structures of authority and responsibility; and courts and various administrative courts and committees have legislators, executives or administrators responsible for the law (Aucoin \& Heintzman, 2000; Stone, 1995; Mulgan, 1997). Transparency without accountability becomes meaningless and makes a mockery of sound public administration. Accountability depends on transparency or having the necessary information both without integrity may not end up serving the public interest (Armstrong, 2005). The accounting system therefore no longer relies on individual public company goals through financial reporting but on a governance based on the consolidated reporting (Levi Faur, 2012; Stoker, 2016). The change is due to a progressive inability of the public company to answer individually to the needs of citizens and stakeholders to whom, in view of subsidiarity, the public company answers (Barnes \& Sullivan, 2007).

The distinction between New Public Management and New Public Governance is critical to understanding the approach used. There is a distinction between vertical and horizontal accountability (Hodges 2012). Vertical accountability refers to "the legal structures underlying public sector organizations, and which conform to the processes of authorization and defined mandates. It is linked to liberal political theory in which bureaucrats deliver outputs while politicians should be responsible for outcomes". Horizontal accountability concerns the moral and social obligations as perceived by organizations to report to stakeholders or the mutual arrangement between bodies of equal standing to provide public services (Bovens, 2007). The accounting systems have been adapted to the changing demands of public governance, which has clearly influenced these systems' use and content (Broadbent and Guthrie, 2008). The growing need for both financial and political accountability demands a broader and more complete set of management and accounting systems to provide feedback for decision-making and for improving accountability (Broadbent et al., 1996; Chan, 2003; Chow et al., 2007; Humphrey et al., 1993, Almqvist et al. 2013).

As indicated above, NPM is primarily based on a vertical and hierarchical view, whereas NPG emphasizes a horizontal focus. In addition, the approaches differ in terms of their scope, i.e., NPM is particularly concentrated on the outputs of individual organizations (result-orientation) while NPG is aimed at results, especially the outcomes of collaborative efforts. NPM represents a 'command and control' manner of using performance information, while the function of performance information within networks is mainly to support processes of debate and dialogue among the partners with different competencies, who are dependent on each other but not in a hierarchical sense. This context promotes clear and accessible performance information (Ahrens and Chapman, 2004; de Bruijn and van Helden, 2006; Wouters, 2009). Different objectives require different types of indicators (Behn 2003). This view could imply that performance information for accountability purposes differs to some extent from that for control purposes. Two aspects may stand out. First, the information in accountability reports is generally more comprehensive than that in control reports, which are particularly focused on the specific tasks and responsibilities of the managers. Second, in control reports the performance indicators selected are related to the concept of controllability, while accountability reports also contain information on elements which are particularly relevant to external stakeholders but outside the scope of the managers and politicians in question. 
Differences also exist in terms of accounting and financial reporting. While NPM is linked to individual organizations using comprehensive concepts of this tools (accrual accounting), NPG has a multi-organizational focus with an interest in "Whole-of-Government Accounting" (WGA) and consolidation issues (Grossi and Newberry, 2009). The consolidated report in the public sector provides an overview of the financial performance and position not only of the single organization but of the whole group of organizations which are under its control and provide public services Table 1 (Broadbent et al., 1996; Chan, 2003; Chow et al., 2007; Almqvist et al 2013).

Table 1. Characteristics new public management and new public governance

\begin{tabular}{|c|c|c|}
\hline & New Public Management (NPM) & New Public Governance (NPG) \\
\hline Focus & Intra-organizational focus & Inter-organizational focus \\
\hline Objectives & $\begin{array}{l}\text { Improving the efficiency and effectiveness of } \\
\text { the single organizations' public service delivery }\end{array}$ & $\begin{array}{l}\text { Improving the inter-organizational coordination and outcomes } \\
\text { of a network of organizations with different competencies }\end{array}$ \\
\hline $\begin{array}{l}\text { Accountability } \\
\text { dimensions }\end{array}$ & $\begin{array}{l}\text { Vertical performance of single organizations } \\
\text { Accountability in terms of results (outputs) }\end{array}$ & $\begin{array}{l}\text { Horizontal performance of the network of organizations } \\
\text { Accountability in terms of the outcome of the network }\end{array}$ \\
\hline $\begin{array}{l}\text { Management } \\
\text { control }\end{array}$ & $\begin{array}{l}\text { Hierarchical control of the results of single } \\
\text { organizations through performance indicators } \\
\text { on efficiency and effectiveness }\end{array}$ & $\begin{array}{l}\text { Enabling control through dialogue-driven systems of } \\
\text { performance indicators, strengthening the contribution of } \\
\text { individual organizations to the network performance }\end{array}$ \\
\hline & $\begin{array}{l}\text { Managing the outputs by assessing the } \\
\text { objectives }\end{array}$ & Governing the outcome by analysis/evaluation of the network \\
\hline Accounting & $\begin{array}{l}\text { Financial reporting of single public } \\
\text { organizations }\end{array}$ & Whole-of-Government Accounting and consolidated reporting \\
\hline
\end{tabular}

Source: Almqvist, R., Grossi, G., van Helden, J., \& Reichard, C. (2013).

The governance and the local public body's ability to manage the external dimension of public services become one of the most important aspects to ensure effectiveness and efficiency of services (Bouckaert et al., 2016; Hodge \& Greve, 2017). Based on the continuous improvement and consolidation approach, you can get an overview that meets all stakeholders' needs (Biancone et al., 2016). To achieve this aim, it is necessary an exchange of useful information and of a monitoring system of performance that is not only internal but also external based on new IT systems (Kouzmin et al., 1999; Korac-Kakabadse, 2001). The focus has shifted to the quality of the information and full availability on good reporting practices using governance tools available to the private group and their implementation to the public group (Shaoul \& Stafford, 2012).

\subsection{Performance and Accountability and Transparency, the Role of Information}

The ability to increase the decision-making process of the public body, of citizens and stakeholders requires some tools that can bring together and synthesize the various information flows by ensuring a true accountability process. Performance evaluation is one of the essential requirements for transparency and accountability in the organization of public services (Reichard, 1998, Pollit \& Summa, 1997). But this is a form of weak responsibility. Often, when only information access is available, an institution is transparent but not responsible. Responsibility includes the capacity to sanction or compensate. The intermediate category refers to the ability to ask for explanations, which is here set as an overlapping area between transparency and accountability (Fox, 2007). Since very often in public bodies the citizen becomes a service provider by unconsciously defining the quality and quantity required (Brusca \& Montesinos, 2006), providing transparent information to ensure a choice is an indispensable element in defining public spending and hence also the taxes that the public body will collect. The possibility of asking for information and the type of data that can be consulted is therefore an issue of analysis. In addition, literature has always stressed the fact that companies are embedded in a dynamic environment with which they are called to evolve, capturing environmental changes in advance and in some ways trying to influence them (Joskow, 1974; Roome, 1992; Oliver \& Holzinger, 2008). Among other things, some of the features that characterize the environment of local Bodies are represented by the increasing need for accountability towards stakeholders (Sternberg, 1997, Belal, 2002, Bäckstrand, 2006, Collier, 2008 Caperchione, 2003) and by the evolution of the same conception of citizen, from that of customer and user of services to that of active stakeholder (Doh \& Guay, 2006; Chess \& Purcell, 1999), able to contribute to the definition of business conduct. What has been has helped to outline a new approach to decision-making and reporting, based on the active involvement of civil society and on a multi-faceted perspective (Moon, 2004; Chen \& Delmas, 2011), and 
it is concretely well corroborated by the remarkable spread of experiences of inclusive decision-making and social reporting processes (Adams, 2002; Deegan, 2002). This is because only the proper understanding of the received information allows those who can correctly contextualize them, to report them, at least potentially, to actual participation dynamics and thus to give them a responsible reading, not prejudiced by the culture of the suspect and mistrust of everything that is done in the exercise of public functions or in any way with the use of public resources. Several studies claim that the revitalization or renewal of local democracy has been characterized by four elements: improving the turnout in local elections; improving community leadership; reforming internal management of local authorities, largely following the private sector guidelines and providing citizens with opportunities to be involved in the decision-making process of local authorities (Boston \& Pallot, 1997; Burns et al., 1994). The relationship between choice and answer from the same subjects announces the introduction of new forms of democracy market in local governments. New mechanisms have been introduced to improve citizen participation and local affairs affecting them, making local authorities and municipalities more sensitive to citizen concerns and increasing available choices (Boston and Pallot, 1997, Wallis \& Dollery, 2001; Northcott et al., 2012). Involvement of citizens and public employees in choice thus becomes one of the key elements leading to a renewal of democracy where key decision-makers and stakeholders are involved in the evaluation system in terms of efficiency and effectiveness (Kelly \& Swindell, 2002) but also in terms of social welfare (Biancone et al., 2017). In the mechanisms introduced to ensure the new forms of democracy, it is imperative to address the issue of transparency and the use of information. Transparency is the ability to provide credible policies by avoiding conflicts of interest, open information and budget sharing, freedom of information and citizen participation in formulating and implementing public policies by making state enterprises responsible (Turnpenny et al. 2009). Transparency therefore concerns ease of access and the use of government and non-profit information. The more getting information is open and easy for the public, the greater transparency is. Yet they recognize that the new technology - the Web, huge databases and computerization - require the protection of confidential personal information (Hood \& Peters, 2004, Willem \& Buelens, 2007).

Valle-Cruz et al. (2016) wondered what technological factors can improve citizens' perception of transparency, efficiency and corruption? And how do these technological factors influence transparency, efficiency and corruption in practice? they found that some emerging technologies are important factors that influence citizens' perceptions of transparency, efficiency and corruption. They suggest that the interaction between government and citizens, supported by information technology, can improve citizens' perceptions of transparency, efficiency and corruption, the use of certain specific technologies (Figure 1).

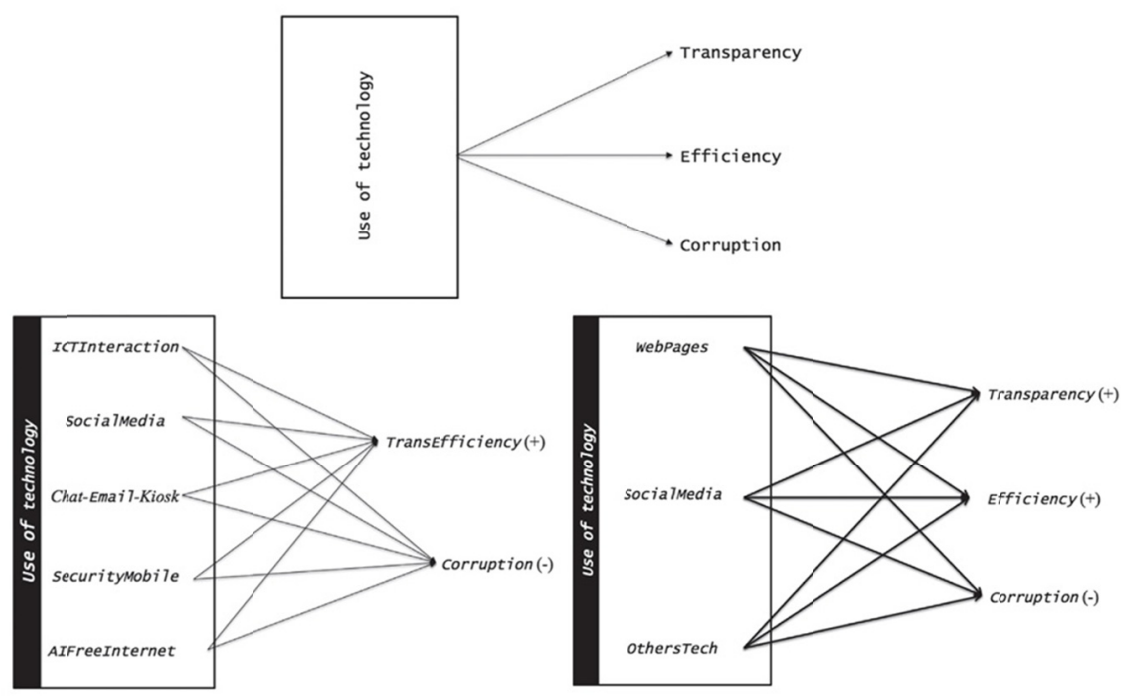

Figure 1. Citizen perceptions model

Source: Valle-Cruz et al. 2016.

\section{Objective and Methodology}

The study wants to analyze whether the use of communication and processing tools in local bodies has a positive relationship on accountability and transparency. The study group used to give evidence of its hypothesis the 
indicators available at Italian national level (Szulanski \& Jensen, 2006). The conducted analysis is quantitative subjective, the theory is demonstrated through the focus of a real case to increase the understanding of theoretical assumptions (Burrell, and Morgan, 1979). The carried-out elaboration, after having identified the variables considered and the possible mathematical relationship between variables, defines the relationship between them through linear regression and through a multivariate statistical analysis.

\subsection{Variables and Correlations Examined}

The relationship between two sociological indicators (citizen's trust in institutions and civic and political participation), which represent the perception of citizen transparency and accountability, and organizational indicators expressed in percentage by the innovative technologies used by public municipalities in their group dimension. The two dependent variables expressed in numerical terms by the citizen (ISTAT, BES 2016) were compared with a series of independent variables linked to the technological and organizational spread of local public entities in Italy with separate valorization by Region (Data ISTAT 2015), data are expressed in appendix. Data on the characteristics and dissemination of open data and IT tools, as well as data on the fission of the internet between families, have been collected by ISTAT, the Italian statistical center that adheres to the Eurostat network, and collects data according to the standards established at Community level. The figures for 2015 relate to the 2016 BES report, which is also drawn up by ISTAT, the indicators and analyzes on well-being that are flanked by the indicators for monitoring the objectives of the 2030 Agenda on sustainable development, the Sustainable Development Goals (SDGs) of the United Nations, chosen by the global community thanks to a political agreement among the different actors, to represent their values, priorities and objectives. The United Statistical Commission of the United Nations (UNSC) has defined a framework of shared statistical information to monitor the progress of individual countries towards the SDGs: over 230 indicators have been identified. The two indicators we use are part of the 230 indicators. The BES data and the ISTAT data are standardized for each region and have been elaborated by the national statistical center. The analysis was conducted through the OLS test (Ordinary Least Squares) and simple regressions to identify the growth of the two variables compared to the percentage of spread of innovative tools in local public municipalities. All analyses were performed via STATA V.14,2 (Stata Corp, College Station, Texas, USA, 2013) with a $\mathrm{p}$ value $<0.05$ considered significant for all analyses. A previous study already dealt with evaluating the relationship between organizational variables and economic variables of public and private companies, also considering technological features (Bretschneider, 1990), but no one considered social repercussion. The analyzes conducted aim to observe the relationship between the two dependent variables and the various independent variables open data in public municipalities, open data by sectors in local bodies (culture, tourism and leisure, education and training and right to study, health, agriculture and forest and food policies, economy, finance and tributes, environment and weather, work and social policies, mobility and transports, energies, justice and security, government and public sector), open data for sectors in local entities (culture, tourism and leisure, education and training and right to study, health, agriculture and forest and food policies, economy, finance and tributes, environment and weather, work and social policies, mobility and transports, energies, justice and security, government and public sector), spread communication and processing tools in local administrations in terms of spread and use (e-mail, office software, database hosting, data archiving, software applications, and calculation power index ), services provided and utilities through IT systems; services and utilities through computer systems, IT structures in local bodies (desktop PCs, laptops, other mobile devices, smart card readers, GIS tools, CAD instruments, GPS handhelds, video conferencing tools, local wireless networks), the percentage of internal employees or co-operating with other P.A., the percentage of internal employees or who cooperate with other P.A., number of families having access to the Internet. All the variables were weighted and are comparable. Political governance variables have not been evaluated in this analysis, focusing attention on the greater role of the citizen in the new public governance taking a leading role in evaluating the service outcomes of the public group and orienting the production of services. The variables that can affect trust in institutions and active participation are shown in Figure 2. 


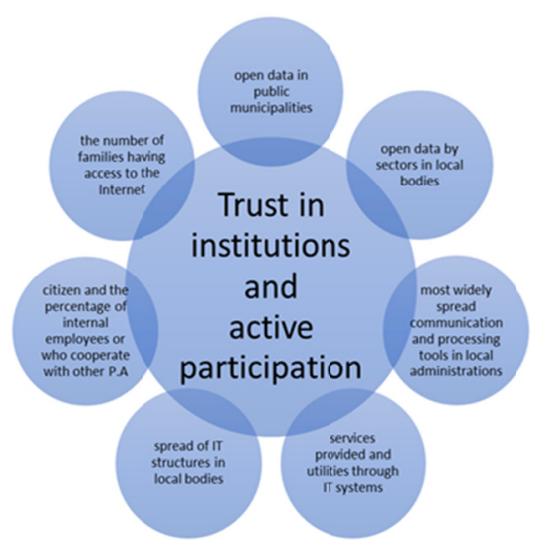

Figure 2. Representation of the variables that can affect trust in institutional and active participation Source: own production.

\subsection{Statistical Indicators}

The role of statistical indicators as a tool to guide and influence decision-making processes is a topic of great relevance, so that it has become the subject of a document (Lisbon Memorandum on "Indicators for decision making and monitoring") (Sèbastien and Bauler, 2013) adopted in 2015 by the general directors of the National Statistical Institutes. If some of the predominantly macroeconomic indicators such as GDP, inflation rate or long-term deficit / GDP ratio have come to full effect in all policy planning cycles, socio-economic and environmental indicators have been consolidated only in recent years their explicit and recognized policy orientation role, despite the debate about their relevance has been going on for half a century. The development and strengthening of statistical indicators on social and environmental aspects and their increased availability have undoubtedly fueled the debate for the construction of an information framework that allows to assess the level of well-being and sustainability over time (Biancone et al., 2017). The BES 2016 report therefore represents some of the social aspects that can be used as variables to analyze the current company organization, considering what features of technological innovation linked to the local administrations by Italian region. Two parameters have been considered: trust in local institutions and citizen's civic and political participation. The two variables are identified respectively in Chapter 6 Indicators by region and geographical distribution point 5 and chapter 5 indicators and composite index by region and geographical distribution point 5 . The variables considered to evaluate how the computerization of the services and tools available to the population have been processed by the tables Table 1.1 - Families with Internet access from home and type of connection by region, geographic distribution and type of municipality - Year 2016 (Data extracted on October 06, 2017, 05h36 UTC-GMT, from I.Stat), Tables Information and Communication Technologies in Local PA (Published Data on January 3, 2017, Reference Period 2015, Istat). The incidence of technology and technology variables of administrations for the year 2015 has been evaluated to assess the impact on the BES social variables of 2016, while the diffusion of the Internet connection, and thus of computerized services and information exchange, has been detected with reference to the year of the survey of the social data having no consequence on the variable.

\section{Discussion}

Citizen perceptions are important for governments, particularly local entities where citizens have more direct impact on political representation and service provision in their communities (Valle-Cruz et al. 2016).

In general, citizen perceptions are conceptualized as how people evaluate and qualify their governments based on the services available and public value they deliver. Citizen perceptions matter when large numbers of people identify specific factors of information or services as problematic; governments then can investigate and resolve the problems. Factors like transparency, accountability, efficiency, corruption, and quality of services are important elements in democratic governments. However, making progress in these areas is a difficult task (Valle-Cruz et al. 2016).

Transparency and openness are key related concerns in contemporary democracies. Transparency is a major driver of online satisfaction and overall trust in government, one of the most important requirements to improve administrative efficiency and citizen satisfaction. There are some studies about local governments that try to explain different components of transparency. Some researchers study how information and communication 
technologies (ICTs) enforce transparency as a mechanism that allows citizen participation and improves economic and social development. Other benefits from ICTs are: (1) citizen engagement, (2) improved service delivery, (3) efficient and transparent administration, (4) improved interactions with other governments, and (5) implementation of public policies (Valle-Cruz et al. 2016).

The resulting evolution of the government-citizen relationship centers in large part on a reimagining of the concept of "citizen coproduction," as this becomes both "more relevant and viable with advances in technology" (Johnston \& Hansen, 2011). In the resulting joint production, citizens contribute more resources in the form of "time, expertise, and effort" to achieve "an outcome, share more responsibility, and manage more risk in return for much greater control over resources and decisions" (Horne \& Shirley, 2009).

However, while the literature - both academic and popular - is rife with preliminary explorations and propositions, it has yet to come together in a coherent and cohesive fashion. Indeed, the emerging phenomenon of Internet-facilitated coproduction has not been systematically studied even if its observers have begun to assign a number of often competing labels - some old, some new: crowdsourcing, "citizen sourcing" (Torres, 2007), "collaborative government" (McGuire, 2006), "Wiki Government" (Noveck, 2009), "open government," "do-it-yourself government" (Dunleavy \& Margetts, 2010), "government as a platform" (O'Reilly, 2010), and much else besides (Linders 2012)

The advent of digitized information and web-connected databases enables the government to deliver highly personalized information to help inform citizens' personal decisions. Government data mining, for instance, could notify users of relevant health risks, useful government programs for which they qualify, and neighborhood crime. Such personalized information can be particularly effective in "nudging" citizens to make socially-beneficial choices. For instance, citizens can be notified of how their real-time energy consumption compares to their neighbors, "shaming" citizens into more responsible behaviors while promoting a friendly competition to the top (Cameron, 2010). Such data mining and dissemination helps citizens make more informed, socially responsible decisions - while reducing the need for government intervention.

The appeal to enhance and expand the viability of and capacity for citizen coproduction, not only in traditional citizen-to-government arrangements ("citizen sourcing"), but also in arrangements whereby the government informs, assists, and enables private actions ("government as a platform") or whereby citizens assist one another, with IT replacing government as vehicle for collective action ("do-it-yourself government"). Advancements in ICT, principally in the form of social media, has enabled these trends by offering promising new vehicles for (a) collective action as always-on connectivity and open government provide an unprecedented mechanism for real-time, community-wide coordination and (b) collective intelligence as mobile-equipped citizens can today complement digital sensors for real-time reporting and comprehensive situational awareness, presenting tremendous opportunities for data-driven decision making, improved performance management, and heightened accountability (Linders 2012)

\section{Results}

\subsection{Trust in Institutions, Civic and Political Participation and Organizational Variables in Local Public Bodies}

Trust in local institutions can be directly proportional to the open-date availability of public bodies (coeff $=0.322$ $\mathrm{p}=0.008$ and $\mathrm{R} 2=0.316$ ) as well as the relationship between citizen's active participation in civic and political life and the open data of public bodies (coeff $=0.353 p=0.015$ and $R 2=0.2719$ ). If we consider as a percentage the number of institutions that make citizen information accessible to individual sectors in local bodies (culture, tourism and leisure, education and training and right to study, health, agriculture and forest and food policies, economy, finance and tributes, environment and weather, work and social policies, mobility and transports, energies, justice and security, government and public sector), there is no proportion between the growth of trust in local institutions and the various sectors considered, perhaps even because of a progressive mistrust with regard to the institutions and the information provided by the policy or the manner and type of information provided; while there is a possible negative relationship between the percentage of institutions providing healthcare information (coefficient $=-0.570 \mathrm{p}=0.041$ ), environment (coef $=-1.157 \mathrm{p}=0.004$ ), work and social policies (coef $=-1.156 \mathrm{p}=0.005$ ) and civic participation, the only distinction between the relationship with the education, training and the right to study that has a positive relationship (coef $=0.911 \mathrm{p}=0.003$ ) all regressions have a $\mathrm{R} 2=0.90$. The analysis may bring to the idea that accessible information in general leads to better public participation and trust in the presence of accessible data and information while at the same time information provided without a single set of perspectives on individual sectors does not lead to trust in local institutions, and some information, often negative due to socially relevant issues, discourages civic or political participation. Cloud usage does not increase citizen's active participation or institutional trust as a functional tool for public 
administrations but not perceptible externally as well as the percentage of municipalities that use database hosting, file storage, and software applications. Going to the most popular tools in local administrations it must be considered the spread and use of e-mail, office software, database hosting, data storage, software applications, and computing power index. The analysis shows a negative correlation between trust in institutions and the percentage of local entities using mails (coefficient- $0.023 p=0.007$ and $R 2=0.72$ ) due to a difficulty of the citizen receiving the information required by the local bodies, the other variables have no significance. A similar assessment is made of the relationship between civic and political participation and some public administration tools, such as the percentage of municipalities using office software (coefficient $=-0.684 p=0.003$ ) and using data storage (coefficient $=-0.521 \mathrm{p}=0.020$ ) where the use of such information tools often disincentives civic and political participation in computational power and the ability to process information could increase citizen's active participation $(\mathrm{R} 2=0.630)$. Considering the relationship between trust in institutions and the percentage of local bodies that provide information and services and benefits, there is a growing trust in institutions in proportion to the percentage of public bodies providing services and utilities (coef $=0.029 \mathrm{p}=0.001$ and $\mathrm{R} 2=$ 0.598); the same phenomenon as regards the growth of political and civic participation compared to the percentage of public bodies that offer services and utilities ( $\operatorname{coef}=0.387 \mathrm{p}=0.001$ and $\mathrm{R} 2=0.590$ ) taking into account the same variables. If we evaluate the spread of IT facilities in local bodies (desktop PC, portable PC, other mobile devices, smart card readers, GIS tools, CAD instrumentation, GPS palmtops, video conferencing tools, local wireless networks) we have a positive correlation between use of smart cards ( $\operatorname{coef}=0.137 \mathrm{p}=0.039$ ) and GIS instruments (coef $=0.035 \mathrm{p}=0.003$ ) with respect to trust placed in institutions $(\mathrm{R} 2=0.854$ ), no significance is linked to citizen's civic participation or politics in respect of the explicit variables. The percentage of internal employees or who cooperate with other P.A. does not affect citizen's civic or political participation, nor the trust placed in the institutions as organizational elements within the structure of which the citizen has no perception. By shifting the focus on the tools the Italian population has in accessing to the Internet and thus the various information provided by IT tools from local governments, it is possible to see growing trust in local institutions in relation to the percentage of citizens who have access to the Internet (coef $=0.074 p=0.007$ and $\mathrm{R} 2=0.326$ ) a positive correlation also between active citizen participation in civic or political life and percentage of citizens who have access to the Internet (coefficient $=1.374 p=0.001$ and $R 2=0.789$ ), in both cases with an growing trend (graph 1 and graph 2). The results also show that without a system, some tools and ways of spreading information can even become counter-productive when offices have a direct relationship with the citizen (for example, exchange of mails or digital work). Information must, however, be provided organically and organized with a structured system that provides a complete view, better if it is not directly communicated to one between local and national public employees. The overall view and the organic offer of open data that are accessible and continuously updated using large data guarantees a better trust of institutions and greater participation in civic and political life. The ability to access the services directly gives rise to greater confidence in the institutions and in the ability to answer and greater participation in civic and political life. The use of tools such as smart cards to certify the provided data increases the perception of security of given information and trust in institutions as well as the definition of information related to data collected through geolocation and GIS tools. Population's access to the Internet is a key tool to increase better access to provided information, increase digital education policies and accessibility could ensure greater accountability and transparency. The revitalization and renewal of local democracy requires special attention to the elements on which the local administration intervenes to increase the use of large data and transparent communication tools. The variables at stake are a lot and it is not possible to observe them all very often but there are several tools and good policy suggestions to accompany the change that has already begun towards new public management. Table 2 shows the results related to the correlation between variables. 
Table 2. Correlation between variables

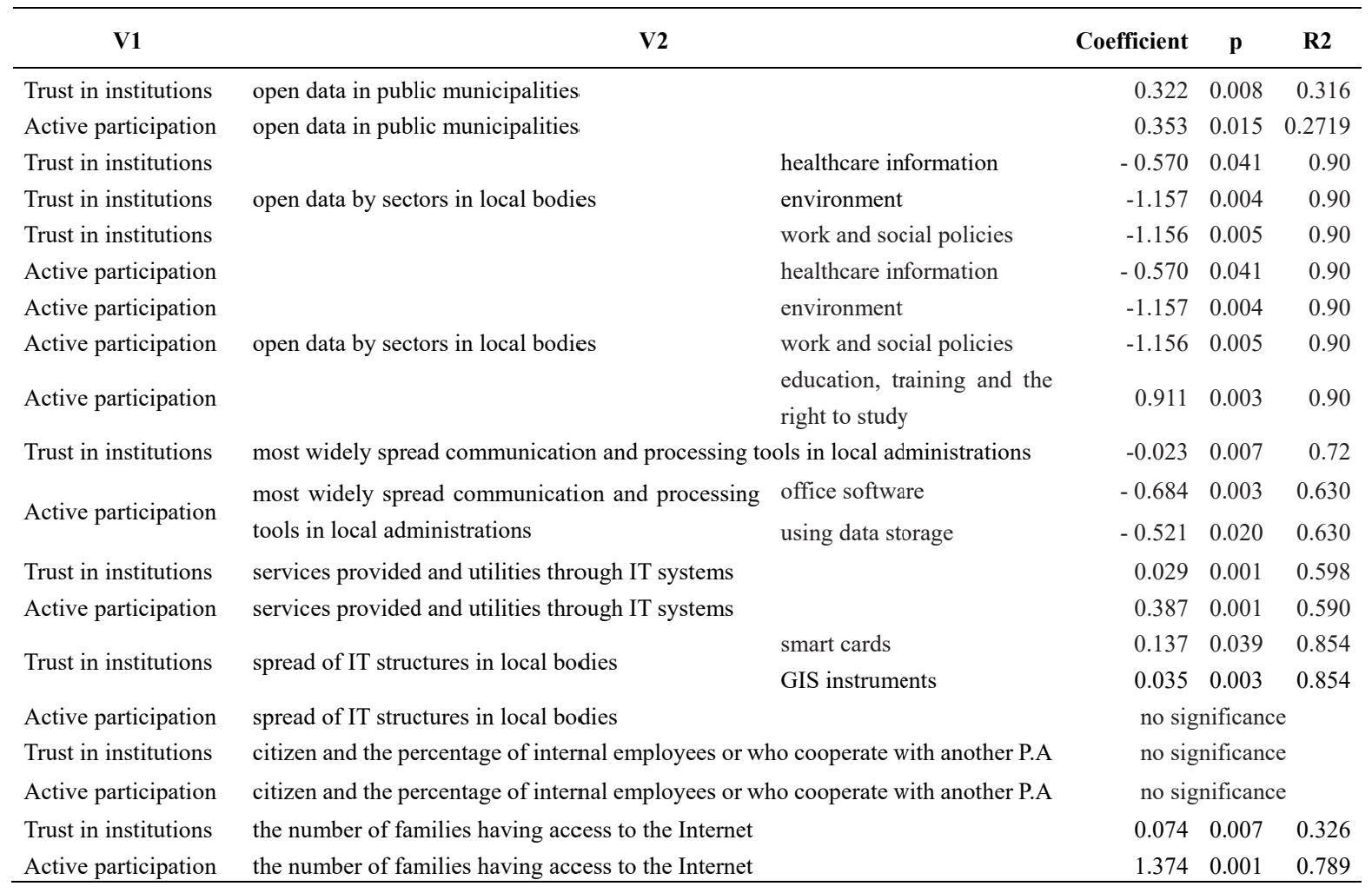

Note. $\mathrm{p}$ value $<0.05$ considered significant for all analyses.

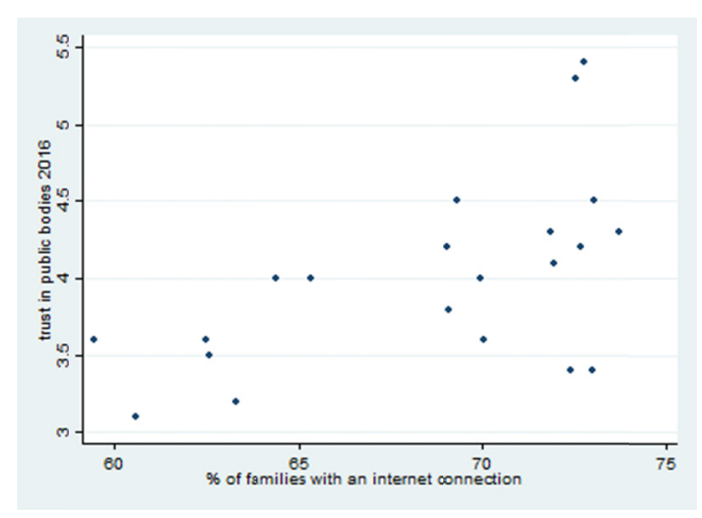

Figure 3. Association between percentage of families with Internet access in regions and trust in public bodies year 2016

Source: own production. 


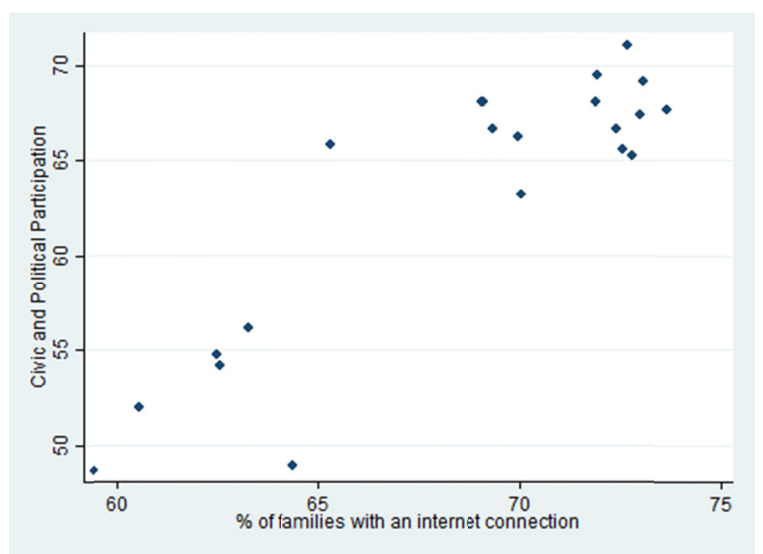

Figure 4. Association between the percentage of families with an Internet connection in regions and participation in civic and political life year 2016

Source: own production.

\section{Conclusion}

With the purpose to identify the role of information in the municipal public group with a view to New Public Governance and the need for mutual exchange between citizens and public bodies we have conclude that the NPG sees public affection closely related to the need for information, this leads to study the real effects towards a new theory of citizen choice. The study shows that the spread of some information and processing tools in local bodies may have a positive impact on trust in local governments or on citizen participation in civic or political life, and thus on transparency and accountability. According the new public management, it is important that the information provided through open organic data on all sectors ensures increased trust in local public bodies and civic participation. The use of social indicators is a useful tool for assessing population satisfaction and understanding of the information provided to better plan and plan public services and interventions of the municipal group. It is also necessary to consider the various organizational tools used in local municipalities before defining an effective social repercussion. It is interesting to note that some direct communication tools used by public offices have a negative impact on local government trust. The spread of Internet among families is a key factor in spreading, increasing transparency and the ability to perceive and analyze the management of local bodies. Accessibility of web information also allows for greater citizen capacity to intervene in civic participation. As in private companies, providing information increases trust in institutions and public service, also increasing participation in public life. The future is towards collaboration and partnership between government and public administration agencies, citizens and other social actors such as the media, academia, the private sector and the third sector. In this process the information plays the most important role (Vigoda, 2002). The progress of public groups will be increasingly in the hands to real owners, citizens. The reduction of available resources requires the identification of priorities, especially when it comes to the definition and production of public services. In many cases the production of services is already based on the needs and preferences expressed on some aspects by the citizen (Cairo et al., 2015). Providing information increases trust and participation by increasing the response to the expressed need that must be met by all public bodies.

\section{References}

Adams, C. A. (2002). Internal organisational factors influencing corporate social and ethical reporting: Beyond current theorising. Accounting, Auditing \& Accountability Journal, 15(2), 223-250 https://doi.org/10.1108/09513570210418905

Ahrens, T., \& Chapman, C. S. (2004). Accounting for flexibility and efficiency: A field study of management control systems in a restaurant chain. Contemporary Accounting Research, 21(2), 271-301 https://doi.org/10.1506/vjr6-rp75-7gux-xh0x

Almqvist, R., Grossi, G., van Helden, J., \& Reichard, C. (2013). Public sector governance and accountability. Critical Perspectives on Accounting, 24(7-8), 479-487 https://doi.org/10.1016/j.cpa.2012.11.005

Andrews, F. M., Bulmer, M., Ferriss, A. L., Gershuny, J., Glatzer, W., Noll, H. H., ... \& Ward, M. (1989). Whatever happened to social indicators? A symposium. Journal of Public Policy, 9(4), 399-399 
https://doi.org/10.1017/s0143814x00008230

Armstrong, E. (2005). Integrity, transparency and accountability in public administration: Recent trends, regional and international developments and emerging issues. United Nations, Department of Economic and Social Affairs, 1-10. Retrieved from http://unpan1.un.org/intradoc/groups/public/documents/un/unpan020955.pdf

Aucoin, P., \& Heintzman, R. (2000). The dialectics of accountability for performance in public management reform. International review of administrative sciences, 66(1), 45-55 https://doi.org/10.1177/0020852300661005

Bäckstrand, K. (2006). Multi-stakeholder partnerships for sustainable development: rethinking legitimacy, accountability and effectiveness. Environmental Policy and Governance, 16(5), 290-306 https://doi.org/10.1002/eet.425

Barnes, M., Newman, J., \& Sullivan, H. C. (2007). Power, participation and political renewal: Case studies in public participation. Policy Press. https://doi.org/10.1332/policypress/9781861346681.003.0009

Behn, R. D. (2003). Why measure performance? Different purposes require different measures. Public Administration Review, 63(5), 586-606 https://doi.org/10.1111/1540-6210.00322

Belal, A. R. (2002). Stakeholder accountability or stakeholder management: A review of UK firms' social and ethical accounting, auditing and reporting (SEAAR) practices. Corporate Social Responsibility and Environmental Management, 9(1), 8-25 https://doi.org/10.1002/csr.5

Biancone, P. P., Secinaro, S., \& Brescia, V. (2016). The Popular Financial Reporting: Focus on Stakeholders-The first European Experience. International Journal of Business and Management, 11(11), 115 https://doi.org/10.5539/ijbm.v11n11p115

Biancone, P. P., Secinaro, S., \& Brescia, V. (2017). Popular financial reporting: Results, expense and welfare markers. African Journal of Business Management, 11(18), 491-501. https://doi.org/10.5897/ajbm2017.8367

Biancone, P., Secinaro, S., \& Brescia, V. (2016). Popular report and Consolidated Financial Statements in public utilities. Different tools to inform the citizens, a long journey of the transparency. International Journal of Business and Social Science, 7(1). http://hdl.handle.net/2318/1558126

Boston, J. (1996). Public management: the New Zealand model. USA: Oxford University Press.

Boston, J., \& Pallot, J. (1997). Linking strategy and performance: Developments in the New Zealand public $\begin{array}{lllll}\text { sector. Journal of Policy Analysis and Management, 382-404 } & \end{array}$ https://doi.org/10.1002/1520-6688(199722)16:3\%3C382::aid-pam18\%3E3.0.co;2-s

Bouckaert, G., Peters, B. G., \& Verhoest, K. (2016). Coordination of Public Sector Organizations. Palgrave Macmillan. https://doi.org/10.1057/9780230275256.

Bovens, M. (2007). Analysing and assessing accountability: A conceptual framework. European Law Journal, 13(4), 447-468. https://doi.org/10.1111/j.1468-0386.2007.00378.x

Bretschneider, S. (1990). Management information systems in public and private organizations: An empirical test. Public Administration Review, 536-545 https://doi.org/10.2307/976784

Broadbent, J., \& Guthrie, J. (2008). Public sector to public services: 20 years of "contextual" accounting research. Accounting, Auditing \& Accountability Journal, 21(2), 129-169 https://doi.org/10.1108/09513570810854383

Broadbent, J., Dietrich, M., \& Laughlin, R. (1996). The development of principal-agent, contracting and accountability relationships in the public sector: conceptual and cultural problems. Critical Perspectives on Accounting, 7(3), 259-284 https://doi.org/10.1006/cpac.1996.0033

Brusca, I., \& Montesinos, V. (2006). Are citizens significant users of government financial information? Public Money and Management, 26(4), 205-209 https://doi.org/10.1111/j.1467-9302.2006.00526.x

Buhalis, D. (1998). Strategic use of information technologies in the tourism industry. Tourism Management, 19(5), 409-421. https://doi.org/10.1016/s0261-5177(98)00038-7

Burrell, G., \& Morgan, G. (1979). Sociology paradigm and organisational analysis: Elements of the Sociology of Corporate Life. https://doi.org/10.4324/9781315242804

Cairo, O., Sendra Salcedo, J., \& Gutierrez-Garcia, J. O. (2015). Crowdsourcing information for 
knowledge-based design of routes for unscheduled public transport trips. Journal of Knowledge Management, 19(3), 626-640. https://doi.org/10.1108/jkm-02-2015-0053

Cameron, D. (2010). The Next Age of Government (Video). TED 2010 [Retrieved from TED 2010 (Video). Retrieved from http://www.ted.com/talks/lang/eng/david_cameron.html

Caperchione, E. (2003). Local government accounting system reform in Italy: a critical analysis. Journal of Public Budgeting, Accounting \& Financial Management, $15(1), \quad 110$. https://doi.org/10.1108/jpbafm-15-01-2003-b007

Cegarra-Navarro, J. G., Sánchez, A. L. G., \& Cegarra, J. L. M. (2012). Creating patient e-knowledge for patients through telemedicine technologies. Knowledge Management Research and Practice, 10(2), 153-163. https://doi.org/10.1057/kmrp.2011.47

Chan, J. L. (2003). Government accounting: an assessment of theory, purposes and standards. Public Money \& Management, 23(1), 13-20. https://doi.org/10.1111/1467-9302.00336

Chen, C. M., \& Delmas, M. (2011). Measuring corporate social performance: An efficiency perspective. $\begin{array}{llll}\text { Production and } \quad \text { Operations } & \text { Management, } & \text { 20(6), } & \text { 789-804. }\end{array}$ https://doi.org/10.1111/j.1937-5956.2010.01202.x

Chess, C., \& Purcell, K. (1999). Public participation and the environment: Do we know what works? Environmental science \& technology, 33(16), 2685-2692. https://doi.org/10.1021/es980500g

Chow, D. S., Humphrey, C., \& Moll, J. (2007). Developing whole of government accounting in the UK: Grand claims, practical complexities and a suggested future research agenda. Financial Accountability \& Management, 23(1), 27-54. https://doi.org/10.1111/j.1468-0408.2007.00418.x

Christensen, T., \& Lægreid, P. (2005). Trust in government: The relative importance of service satisfaction, political factors, and demography. Public Performance \& Management Review, 28(4), 487-511. https://doi.org/10.1080/15309576.2005.11051848

Cnel, I. (2017). Rapporto Bes 2016-Il Benessere equo e sostenibile in Italia. Retrieved from https://www.istat.it/it/archivio/207259

Collier, P. M. (2008). Stakeholder accountability: A field study of the implementation of a governance improvement plan. Accounting, Auditing \& Accountability Journal, 21(7), 933-954 https://doi.org/10.1108/09513570810907429

De Bruijn, H., \& Van Helden, G. J. (2006). A plea for dialogue driven performance-based management systems: evidence from the Dutch public sector. Financial Accountability \& Management, 22(4), 405-423. https://doi.org/10.1111/j.1468-0408.2006.00432.x

Deegan, C. (2002). Introduction: The legitimising effect of social and environmental disclosures-a theoretical foundation. Accounting, Auditing \& Accountability Journal, 15(3), 282-311. https://doi.org/10.1108/09513570210435852

Doh, J. P., \& Guay, T. R. (2006). Corporate social responsibility, public policy, and NGO activism in Europe and the United States: An Institutional-Stakeholder perspective. Journal of Management Studies, 43(1), 47-73. https://doi.org/10.1111/j.1467-6486.2006.00582.x

Dunleavy, P., \& Margetts, H. Z. (2010). The second wave of digital era governance. APSA 2010 Annual Meeting Papers. Retrieved from http://eprints.lse.ac.uk/27684/1/The_second_wave_of_digital_era_governance_(LSERO).pdf

Erdem, T., \& Swait, J. (2004). Brand credibility, brand consideration, and choice. Journal of Consumer Research, 31(1), 191-198. https://doi.org/10.1086/383434

Farnham, D., Hondeghem, A., Horton, S., \& Barlow, J. (Eds.). (2016). New public managers in Europe: Public servants in transition. https://doi.org/10.1007/978-1-349-13947-7

Fornell, C., Rust, R. T., \& Dekimpe, M. G. (2010). The effect of customer satisfaction on consumer spending growth. Journal of Marketing Research, 47(1), 28-35. https://doi.org/10.1509/jmkr.47.1.28

Fox, J. (2007). The uncertain relationship between transparency and accountability. Development in Practice, 17(4-5), 663-671. https://doi.org/10.1080/09614520701469955

Glatzer, W. (2015). Worries and pain-The dark side of quality of life. In Global Handbook of Quality of Life (pp. 855-868). https://doi.org/10.1007/978-94-017-9178-6_40 
Goddard, A. (2005). Accounting and NPM in UK local government-contributions towards governance and accountability. Financial Accountability \& $\quad$ Management, $\quad 21(2), \quad 191-218$ https://doi.org/10.1111/j.1468-0408.2005.00215.x

Goodrich, J. N. (1978). The relationship between preferences for and perceptions of vacation destinations: Application of a choice model. Journal of Travel Research, 17(2), 8-13 https://doi.org/10.1177/004728757801700202

Grossi, G., Newberry, S., Bergmann, A., Bietenhader, D., Tagesson, T., Christiaens, J., ... \& Rommel, J. (2009). Theme: Whole of government accounting-international trends. https://doi.org/10.1080/09540960903034968.

Hagerty, M. R., \& Land, K. C. (2007). Constructing summary indices of quality of life: A model for the effect of heterogeneous importance weights. Sociological Methods \& Research, 35(4), 455-496 https://doi.org/10.1177/0049124106292354

Hodge, G. A., \& Greve, C. (2017). On public-private partnership performance: A contemporary review. Public Works Management \& Policy, 22(1), 55-78 https://doi.org/10.1177/1087724x16657830

Hodges, R. (2012). Joined-up government and the challenges to accounting and accountability researchers. Financial Accountability \& Management, 28(1), 26-51 https://doi.org/10.1111/j.1468-0408.2011.00535.x

Hood, C. (1991). A public management for all seasons? Public administration, 69(1), 3-19. https://doi.org/10.1111/j.1467-9299.1991.tb00779.x

Hood, C. (1995). The "New Public Management" in the 1980s: variations on a theme. Accounting, organizations and society, 20(2-3), 93-109 https://doi.org/10.1016/0361-3682(93)e0001-w

Hood, C., \& Peters, G. (2004). The middle aging of new public management: into the age of paradox? Journal of public administration research and theory, 14(3), 267-282 https://doi.org/10.1093/jopart/muh019

Horne, M., \& Shirley, T. (2009). Co-production in public services: A new partnership with citizens (Discussion Paper). U.K.: Cabinet Office [The Strategic Unit]. Retrieved from http://webarchive.nationalarchives.gov.uk/+/http:/www.cabinetoffice.gov.uk/media/207033/public_services _co-production.pdf

Hu, H. H., Kandampully, J., \& Juwaheer, T. D. (2009). Relationships and impacts of service quality, perceived value, customer satisfaction, and image: an empirical study. The Service Industries Journal, 29(2), 111-125 https://doi.org/10.1080/02642060802292932

Humphrey, C., Miller, P., \& Scapens, R. W. (1993). Accountability and accountable management in the UK public sector. Accounting, Auditing \& Accountability Journal, $6(3)$. https://doi.org/10.1108/09513579310042542

Jacobs, R., \& Goddard, M. (2007). How do performance indicators add up? An examination of composite indicators in public services. Public Money and Management, 27(2), 103-110. https://doi.org/10.1111/j.1467-9302.2007.00565.x

Jacoby, J., Speller, D. E., \& Berning, C. K. (1974). Brand choice behavior as a function of information load: Replication and extension. Journal of consumer research, 1(1), 33-42. https://doi.org/10.1086/208579

Jacoby, J., Speller, D., \& Kohn, C. (1974). Brand Choice Behavior as a Function of Information Load. Journal of Marketing Research, 11(1), 63-69. https://doi.org/10.2307/3150994

Johnston, E., \& Hansen, D. (2011). Design lessons for smart governance infrastructures. In D. Ink, A. Balutis, \& T. Buss (Eds.), American Governance 3.0: Rebooting the Public Square? National Academy of Public Administration. http://nationalresourcenetwork.org/Documents/Document/Document/301940

Joskow, P. L. (1974). Inflation and environmental concern: Structural change in the process of public utility price regulation. The Journal of Law and Economics, 17(2), 291-327 https://doi.org/10.1086/466794

Kelly, J. M., \& Swindell, D. (2002). A multiple-indicator approach to municipal service evaluation: correlating performance measurement and citizen satisfaction across jurisdictions. Public Administration Review, 62(5), 610-621. https://doi.org/10.1111/1540-6210.00241

Kim, S., \& Lee, J. (2012). E-participation, transparency, and trust in local government. Public Administration Review, 72(6), 819-828. https://doi.org/10.1111/j.1540-6210.2012.02593.x

Klijn, E. H. (2008). Governance and governance networks in Europe: An assessment of ten years of research on 
the theme. Public management review, 10(4), 505-525. https://doi.org/10.1080/14719030802263954

Korac-Kakabadse, N., \& Kakabadse, A. (2001). IS/IT governance: Need for an integrated model. Corporate Governance: The International Journal of Business in Society, 1(4), 9-11. https://doi.org/10.1108/eum0000000005974

Kouzmin, A., Löffler, E., Klages, H., \& Korac-Kakabadse, N. (1999). Benchmarking and performance measurement in public sectors: Towards learning for agency effectiveness. International Journal of Public Sector Management, 12(2), 121-144. https://doi.org/10.1108/09513559910263462

Kozak, M. (2000). Destination benchmarking: facilities, customer satisfaction and levels of tourist expenditure (Doctoral dissertation, Sheffield Hallam University). Retrieved from http://shura.shu.ac.uk/3156/

Land, K. C. (Ed.). (2012). The well-being of America's children: Developing and improving the child and youth well-being index (Vol. 6). https://doi.org/10.1007/978-94-007-4092-1

Levi-Faur, D. (Ed.). (2012). The Oxford handbook of governance. Oxford University Press. https://doi.org/10.1093/oxfordhb/9780199560530.001.0001

Linders, D. (2012). From e-government to we-government: Defining a typology for citizen coproduction in the age of social media. Government Information Quarterly, 29(4), 446-454. https://doi.org/10.1016/j.giq.2012.06.003

Lovato, E., Bert, F., Bruno, S., Ceruti, M., De Vito, E., La Torre, G., Liguori, G., Manzoli, L., Messina, G., Minniti, D., \& Siliquini, R. (2011). Role of the Web on behaviors and health choices in six Italian cities: results of a multicenter study. Collaborative Group, Ann Ig., Jul-Aug, 23(4), 283-94. https://doi.org/10.1186/1472-6947-11-21

McGuire, M. (2006). Collaborative public management: Assessing what we know and how we know it. Public Administration Review, 66, 33-43. https://doi.org/10.1111/j.1540-6210.2006.00664.x

Melone, N. P. (1990). A theoretical assessment of the user-satisfaction construct in information systems research. Management science, 36(1), 76-91. https://doi.org/10.1287/mnsc.36.1.76

Moon, J. (2004). Government as a driver of corporate social responsibility: The UK in comparative perspective. Retrieved from http://citeseerx.ist.psu.edu/viewdoc/download?doi=10.1.1.198.8346\&rep=rep1\&type=pdf

Mulgan, R. (1997). Contracting out and accountability. Australian Journal of Public Administration, 56(4), 106-116. https://doi.org/10.1111/j.1467-8500.1997.tb02493.x.

Mulgan, R. (2002). Public accountability of provider agencies: the case of the Australian 'Centrelink'. International Review of Administrative Sciences, 68(1), 45-59. https://doi.org/10.1177/0020852302681003.

Northcott, D., \& Ma'amora Taulapapa, T. (2012). Using the balanced scorecard to manage performance in public sector organizations: Issues and challenges. International Journal of Public Sector Management, 25(3), 166-191. https://doi.org/10.1108/09513551211224234.

Noveck, B. (2009). Wiki government: How technology can make government better, democracy stronger, and citizens more powerful. Washington, DC: Brookings Institutions Press Retrieved from https:/tidsskrift.dk/mediekultur/article/download/5731/5779

Oliver, C., \& Holzinger, I. (2008). The effectiveness of strategic political management: A dynamic capabilities framework. Academy of Management Review, 33(2), 496-520. https://doi.org/10.5465/amr.2008.31193538

O'Reilly, T. (2010). Government as a Platform (Chap 2). In D. Lathrop, \& L. Ruma (Eds.), Open government: Collaboration, transparency, and participation in practice: O'Reilly Media. https://doi.org/10.1162/inov_a_00056

Osborne, D., \& Gaebler, T. (1992). Reinventing government: How the entrepreneurial spirit is transforming government. $\quad$ Reading $\quad$ Mass. $\quad$ Retrieved from https://scholarworks.wmich.edu/cgi/viewcontent.cgi?referer=https://www.google.it/\&httpsredir=1\&article= 2116\&context=jssw

Osborne, D., \& Plastrik, P. (1997). Banishing Bureaucracy: The Five Strategies for Reinventing Government. Addison-Wesley Publishing Company, Inc., I Jacob Way, Reading, MA 01867. Retrieved from https://eric.ed.gov/?id=ED423582

Pollitt, C., \& Bouckaert, G. (2004). Public management reform: A comparative analysis. USA: Oxford University Press. 
Pollitt, C., \& Bouckaert, G. (2011). Public Management Reform: A comparative analysis-new public management, governance, and the Neo-Weberian state. Oxford University Press https://doi.org/10.1177/0020852312437323

Pollitt, C., \& Summa, H. (1997). Trajectories of reform: public management change in four countries. Public Money and Management, 17(1), 7-18. https://doi.org/10.1111/1467-9302.00051

Pollitt, C., Girre, X., Lonsdale, J., Mul, R., Summa, H., \& Waerness, M. (1999). Performance or compliance? Performance audit and public management in five countries. Oxford: Oxford University Press https://doi.org/10.1093/acprof:oso/9780198296003.001.0001

Reichard, C. (1998). The impact of performance management on transparency and accountability in the public sector. In Annie Hondeghem (Ed.), Ethics and accountability in a context of governance and New Public Management (pp. 123-37).

Relly, J. E., \& Sabharwal, M. (2009). Perceptions of transparency of government policymaking: A cross-national study. Government Information Quarterly, 26(1), 148-157. https://doi.org/10.1016/j.giq.2008.04.002

Roome, N. (1992). Developing environmental management strategies. Business strategy and the environment, 1(1), 11-24. https://doi.org/10.1002/bse.3280010104

Sébastien, L., \& Bauler, T. (2013). Use and influence of composite indicators for sustainable development at the EU-level. Ecological indicators, 35, 3-12. https://doi.org/10.1016/j.ecolind.2013.04.014

Shaoul, J., Stafford, A., \& Stapleton, P. (2012). Accountability and corporate governance of public private partnerships. Critical Perspectives on Accounting, 23(3), 229. https://doi.org/10.1016/j.cpa.2011.12.006

Siliquini, R., Ceruti, M., Lovato, E., Bert, F., Bruno, S., De Vito, E., ... \& La Torre, G. (2011). Surfing the internet for health information: an italian survey on use and population choices. BMC medical informatics and Decision Making, 11(1), 21. https://doi.org/10.1186/1472-6947-11-21

Sivadas, E., \& Baker-Prewitt, J. L. (2000). An examination of the relationship between service quality, customer satisfaction, and store loyalty. International Journal of Retail \& Distribution Management, 28(2), 73-82. https://doi.org/10.1108/09590550010315223

Sternberg, E. (1997). The defects of stakeholder theory. Corporate Governance: An International Review, 5(1), 3-10. https://doi.org/10.1111/1467-8683.00034

Stoker, G. (2006). Public value management: a new narrative for networked governance? The American review of public administration, 36(1), 41-57. https://doi.org/10.1177/0275074005282583

Stone, N. (1995). The management and practice of public relations. Macmillan.

Szulanski, G., \& Jensen, R. J. (2006). Presumptive adaptation and the effectiveness of knowledge transfer. Strategic Management Journal, 27(10), 937-957. https://doi.org/10.1002/smj.551

Torres, L. (2007). Citizen sourcing in the public interest. Knowledge Management for Development Journal, 3(1), 134-145. http://km4djournal.org/index.php/km4dj/article/view/103

Turnpenny, J., Radaelli, C. M., Jordan, A., \& Jacob, K. (2009). The policy and politics of policy appraisal: emerging trends and new directions. Journal of European Public Policy, 16(4), 640-653 https://doi.org/10.1080/13501760902872783

Valle-Cruz, D., Sandoval-Almazan, R., \& Gil-Garcia, J. R. (2016). Citizens' perceptions of the impact of information technology use on transparency, efficiency and corruption in local governments. Information Polity, 21(3), 321-334. https://doi.org/10.3233/ip-160393

Van Dooren, W., Bouckaert, G., \& Halligan, J. (2015). Performance management in the public sector. Routledge.

Vigoda, E. (2002). From responsiveness to collaboration: Governance, citizens, and the next generation of public administration. Public administration Review, 62(5), 527-540 https://doi.org/10.1111/1540-6210.00235

Wallis, J., \& Dollery, B. (2001). Local government policy evolution in New Zealand: radical reform and the ex post emergence of consensus or rival advocacy coalitions. Public Administration, 79(3), 533-560. https://doi.org/10.1111/1467-9299.00268

Wang, X., \& Van Wart, M. (2007). When public participation in administration leads to trust: An empirical assessment of managers' perceptions. Public Administration Review, 67(2), 265-278. https://doi.org/10.1111/j.1540-6210.2007.00712.x 
Willem, A., \& Buelens, M. (2007). Knowledge sharing in public sector organizations: The effect of organizational characteristics on interdepartmental knowledge sharing. Journal of Public Administration Research and Theory, 17(4), 581-606. https://doi.org/10.1093/jopart/mul021

Wouters, M. (2009). A developmental approach to performance measures-Results from a longitudinal case study. European Management Journal, 27(1), 64-78. https://doi.org/10.1016/j.emj.2008.06.006

\section{Appendix}

Statistical analysis table

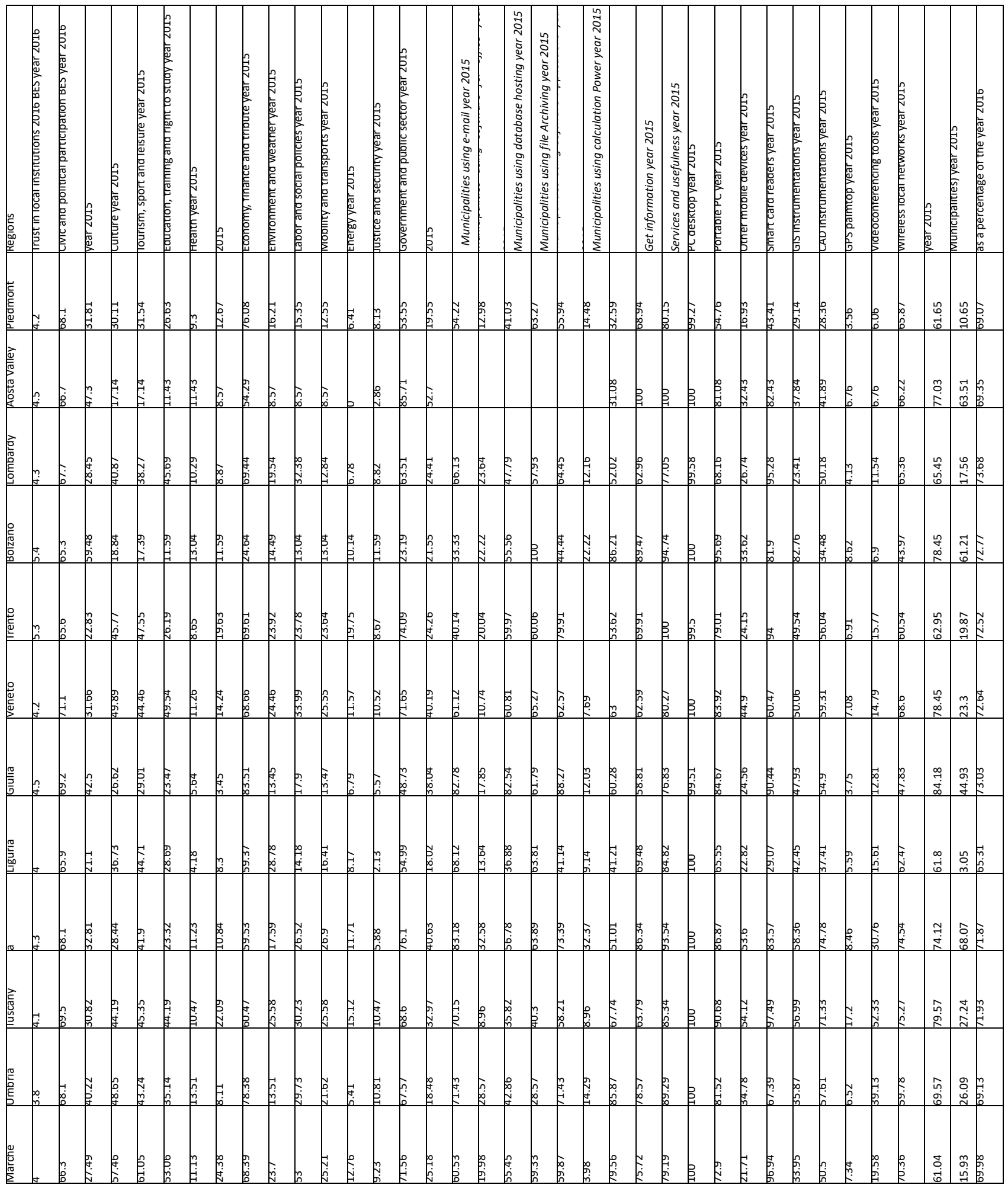




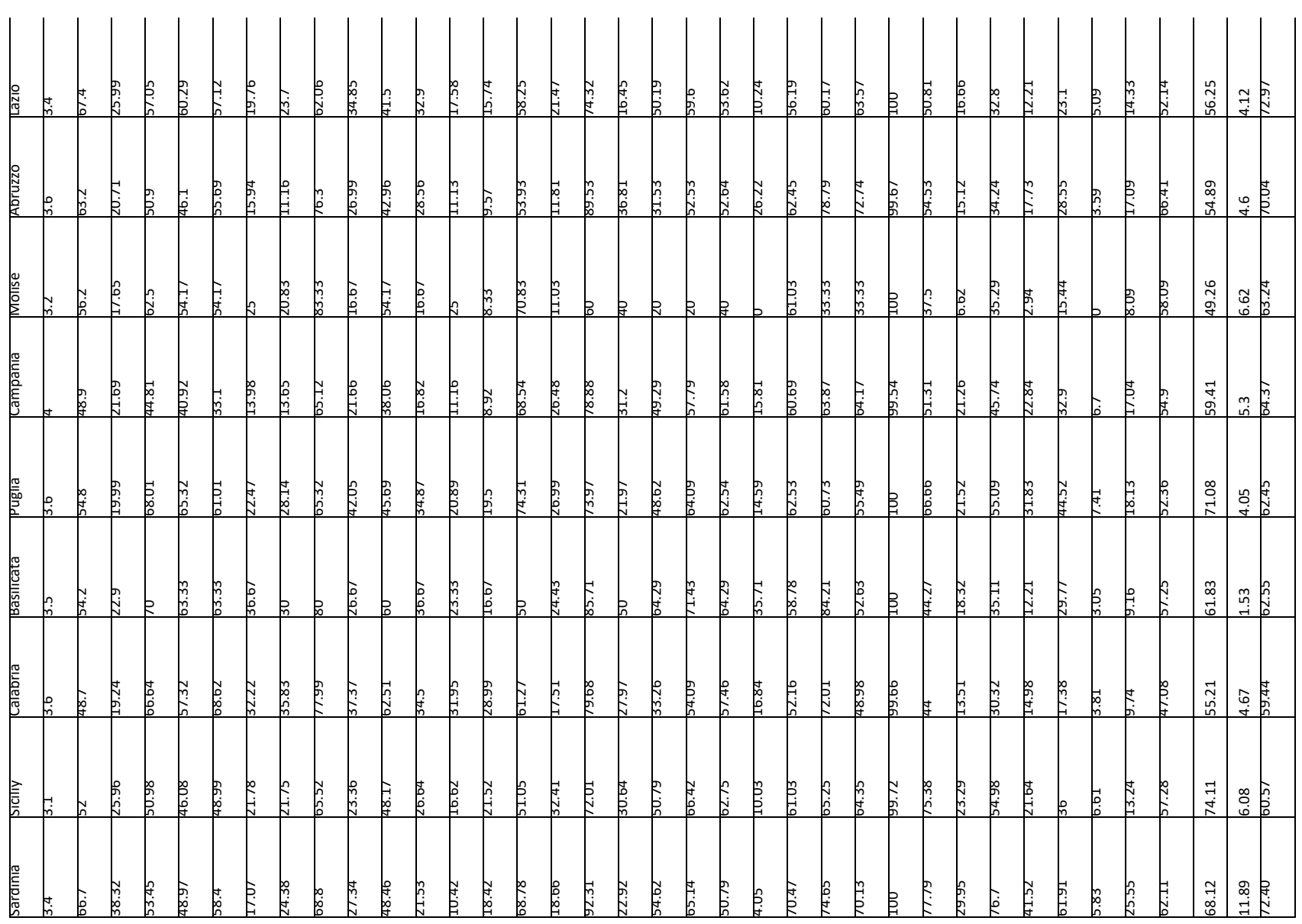

\section{Copyrights}

Copyright for this article is retained by the author(s), with first publication rights granted to the journal. This is an open-access article distributed under the terms and conditions of the Creative Commons Attribution license (http://creativecommons.org/licenses/by/4.0/). 